\title{
MANUFACTURING AND TESTING OF CARBON COMPOSITE SAMPLES INTENDED FOR AVIATION
}

\author{
RAfae Szymański, Mateusz ZięBA* \\ * Composite Technology Center, Institute of Aviation, Al. Krakowska 110/114, 02-256 Warszawa \\ rafal.szymanski@ilot.edu.pl,mateusz.zieba@ilot.edu.pl
}

\begin{abstract}
The paper presents the manufacturing technology and quality control of samples made of composite materials intended, inter alia, for aircraft elements. The samples are made from carbon fiber reinforced prepreg in a polymer matrix which is commonly used in the aerospace industry. The authors described the dimensional requirements for samples made of composite materials for strength testing, and the main stages of production which have a direct impact on the quality of composite samples. Also presented is the technological process of producing flat carbon composite panels for composite samples, cutting the produced panels with a CNC plotter, cutting the samples on a conventional milling machine, and surface treatment of the samples on a surface grinder. The machining parameters that were experientially found to be optimal for the milling and grinding of carbon samples are specified as well. Finally, the method of quality control of the ready composite samples is described and solutions are presented to improve the production of high-quality samples.

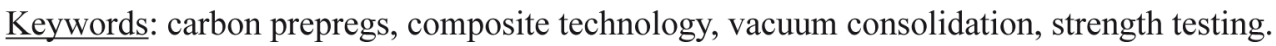

\section{INTRODUCTION}

Current trends in the aerospace industry make it likely that carbon composites will continue to be one of the basic materials in aircraft construction. In 2004, Airbus produced the A380 passenger aircraft, comprising 22\% (of the total mass) CFRP (Carbon Fiber Reinforced Polymers) composites. In 2009, the Boeing 787 Dreamliner was produced, comprised of 50\% carbon composite $[8 \div 10]$. The tendency to increase the use of composites in aviation is not limited to CFRP (Carbon Fiber Reinforced Polymers) but also includes high-temperature thermoplastic prepregs [7]. Additionally, the Institute of Aviation carries out continuous research on improving the strength properties of composite structures by adding graphene $[13 \div 16]$ to the carbon composite. Low weight and high durability put these materials at the forefront of the aviation 
world. The Institute of Aviation is one of the world's leading research centers providing composite testing services for domestic and foreign clients [1]. Machining of such materials is complicated. Determining the processing parameters for pre-impregnated carbon panels is important since the quality and production time of the composite product depends on the parameters chosen. The processes described in this article allow its readers to enhance their knowledge of the precise preparation of carbon composite samples. The auxiliary processes associated with the production of carbon samples used in the CKTT Department of the Aviation Institute are also described in detail. This paper includes descriptions of the technology of composite sample preparation using a vacuum ironing table, the system of pre-cutting panels (so-called subpanels) with a CNC plotter, precision cutting of target specimens with a conventional milling machine using diamond discs, grinding with a surface grinder of sample edges that are key for testing, checking the quality of the samples to ensure they are in compliance with ASTM D6641 / D6641M-14 (2014) [2].

\section{COMPOSITE SAMPLE PREPARATION TECHNOLOGY}

\subsection{Manufacturing of pre-impregnated carbon panels}

The CKT Division mainly conducts research on composite materials (CFRP) produced using the pre-impregnate technology $[11 \div 12]$. Carbon fiber fabrics are pre-impregnated with epoxy resin. The pre-impregnated fabric was laid out on a flat duralumin plate measuring 300x300 mm, which served as the mold in the process (Fig. 1). Using the vacuum table (Fig. 2), the pre-impregnated layers were compressed $1 \div 3$ layers at a time. After obtaining the target number of layers, the composite panel along with the duralumin sheet was placed in a sealed vacuum bag.

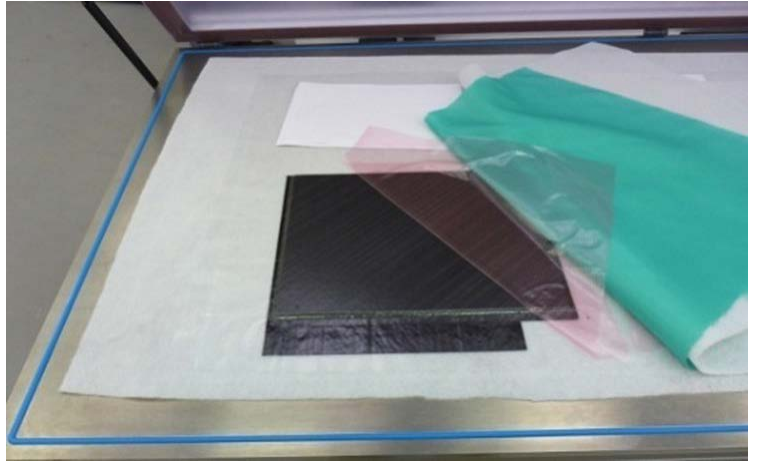

Fig. 1. Compression of a carbon prepreg layer [The Author 2016]

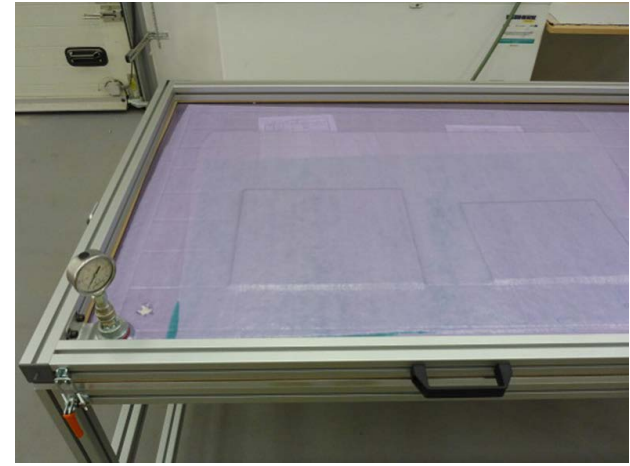

Fig. 2. Compressing with a vacuum table [The Author 2016]

A previously prepared vacuum bag with a composite panel was placed in the furnace to perform the polymerization of the epoxy resin contained in the pre-impregnate. The process was carried out under maintained negative pressure (-0.98 bar) in the vacuum bag. The curing process is divided into two stages:

1. pre-hardening,

2. target curing.

Pre-hardening consisted of curing the composite material in a vacuum bag at $82^{\circ} \mathrm{C}$. 
After the pre-hardening, the composite panel was removed from its mold and cured, no mold, at $130^{\circ} \mathrm{C}$ (Fig. 3). The curing graphs show changes in process temperature over time for the MTM-46 resin. The above process stages enabled a reduction in the porosity of the composite structure to $3 \div 5 \%$ (Fig.4).
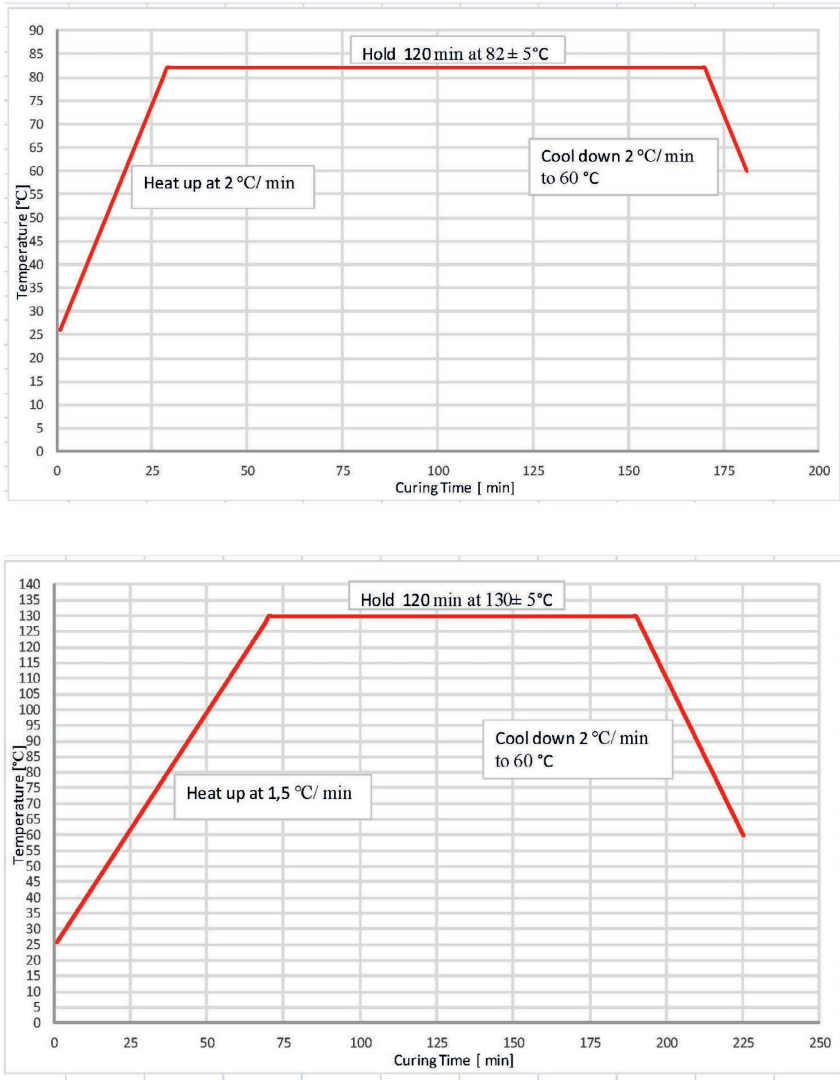

Fig. 3. Graph of thermal cycles for MTM46 resin: 1 - Pre-hardening process, 2 - Target curing process [The Author 2016]

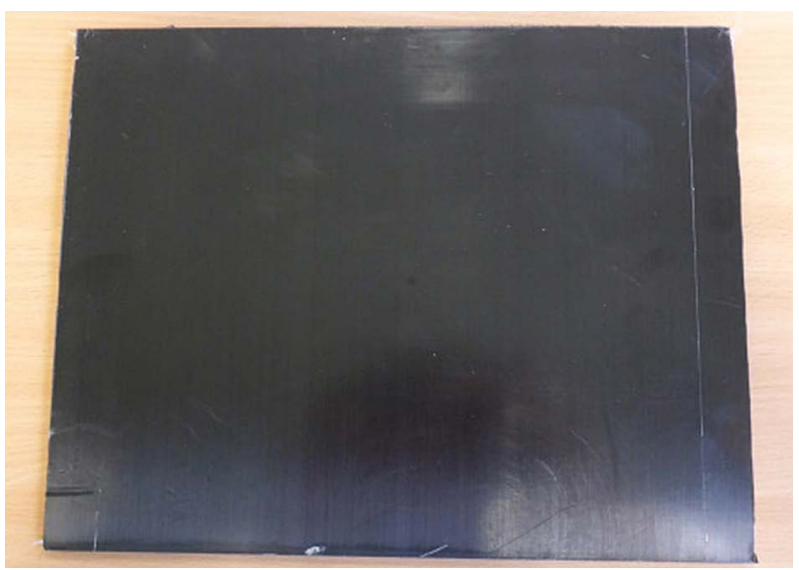

Fig.4. Cured composite panel [The Author 2016] 


\subsection{Preliminary cutting of composite samples on a CNC plotter}

The next step in the preparation of the samples is their preliminary cutting (into subpanels). An important problem in the machining of composites is their layered structure, while another is the short life of the tools. Manufacturers try to adapt to these conditions the shape of the tools, the materials they are made of, and their coverage. All that is left to the machine operator is to set proper working parameters. The most important of which are the cutting speed and the feed rate [4].

The use of a milling plotter made the preparation of the laminate subpanels for the next operation (Fig.5) quick and sufficiently accurate. This task is important because the selection of the cutting speed is crucial for the quality of the sample edge. The cutting speed of $100 \div 130 \mathrm{~m} / \mathrm{min}$ yielded optimum working conditions. Delamination in the form of: fraying, chipping, or cracking of the sample edge is the main threat that may occur at this stage of sample preparation. Any discontinuities in the composite structure that are created at the cutting stage may lead to strength reduction of the composite samples. In order to avoid delamination around the edges of the samples, the subpanels were cut with a $20 \mathrm{~mm}$ allowance (around the circumference). It is also important not to overheat the sample edge beyond the resin glass transition temperature $\left(150^{\circ} \mathrm{C}\right)$. Local temperature increase can be reduced by using water-based coolants or by decreasing the depth of the cut and the cutting speed. (Using oil coolants is not recommended because oil inclusions may form in the composite structure. Such inclusions can act as a barrier for water, preventing it from penetrating deep into the studied structure and thus, e.g., making it impossible to verify the aging process of the sample.)

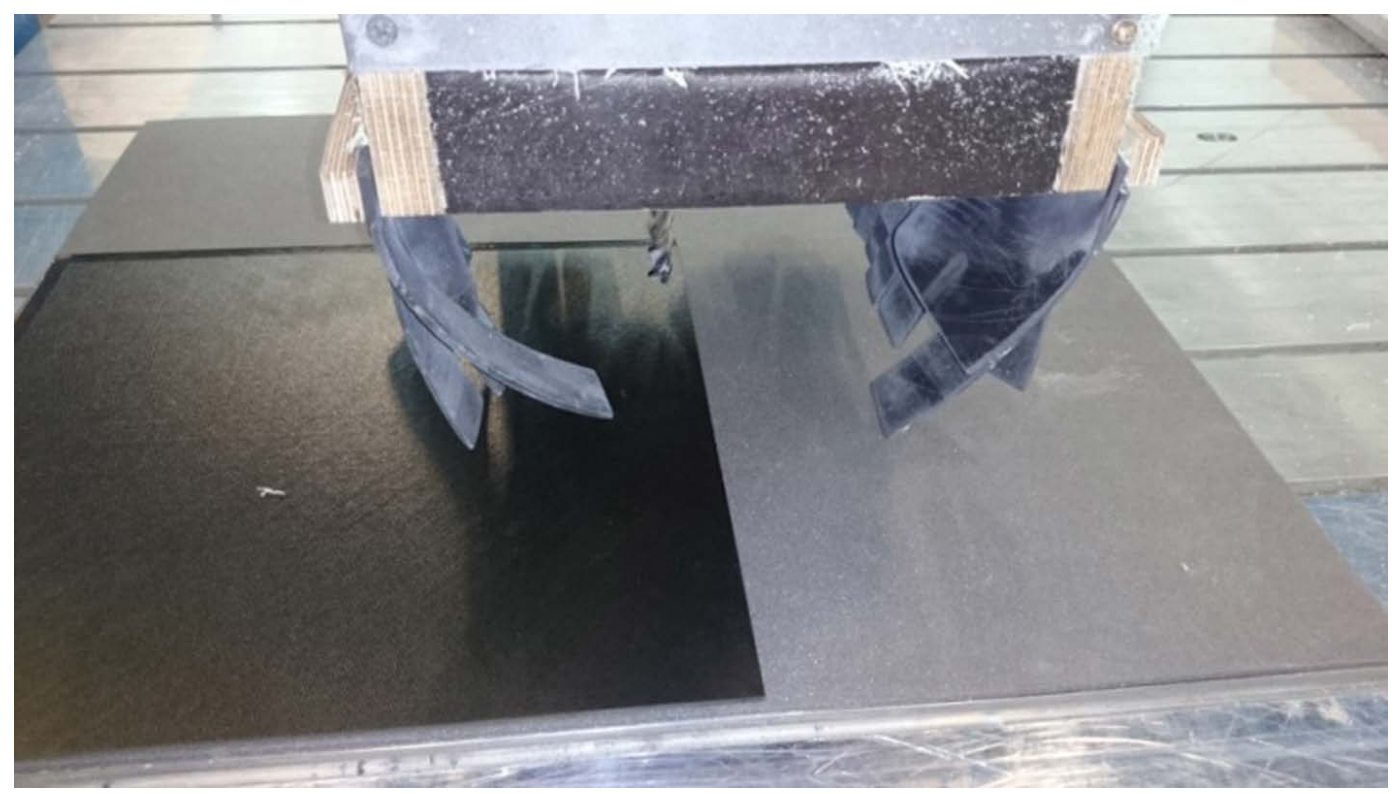

Fig. 5. A sample prepared for milling [The Author 2016] 


\subsection{Cutting of composite samples on a conventional milling machine}

In order to obtain high quality samples, the method used was that of cutting with a diamond disc on a conventional milling machine. The main criterion for assessing the quality of the cut is the number of frayed carbon fibers that appear afterwards. The instrument featured in Fig.6, used for cutting composite samples, allows for the initial setting and maintenance of straight angles of the sample. For the cutting, a clamping system was used, the sample was immobilized, and the edge being cut was supported. The optimum cutting speed of the sample is $0.1 \div 0.4 \mathrm{~m} / \mathrm{min}$. Cutting parameters vary depending on the thickness of the workpiece. Continuous air extraction from the cutting area reduces the operating temperature of the diamond grinding disc and keeps the air free of volatile particles of carbon and resin.

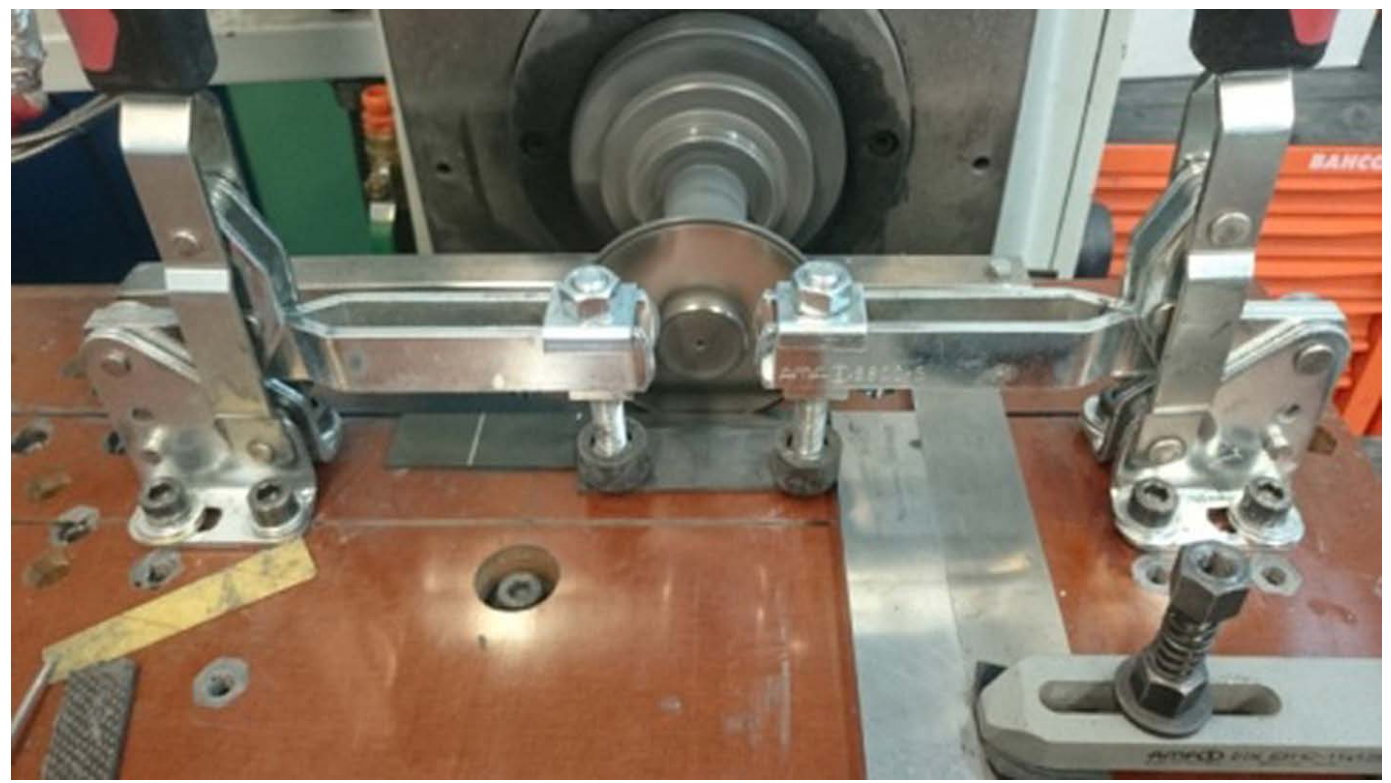

Fig. 6. Sample cutting process on a conventional milling machine [The Author 2016]

\subsection{Grinding on a surface grinder}

The final step in the production of the samples is to remove any scratches and frayed fibers from the surface of the cut samples. Geometric notches created at the cutting stage are a source of cracks leading to disruption of the testing process and to possible alteration of measurement results.

Obtaining a surface free of such faults is directly dependent on the machining parameters. For the grinding of the composite samples, a porous grinding wheel with a ceramic grain of $50 \div 80$ grit was used. The interstices between the grains allow for efficient rinsing out of the cut material from the space between the grains. The cutting speed was $10 \div 20 \mathrm{~m} / \mathrm{min}$. Grinding was performed with a coolant neutral to the composite material. The roughness of the obtained surface should be at least $\mathrm{Ra}=0,8$ with no frayed fibers protruding at all. The edges of the sanded specimens should be homogeneous and free from inclusions (Fig.7). 


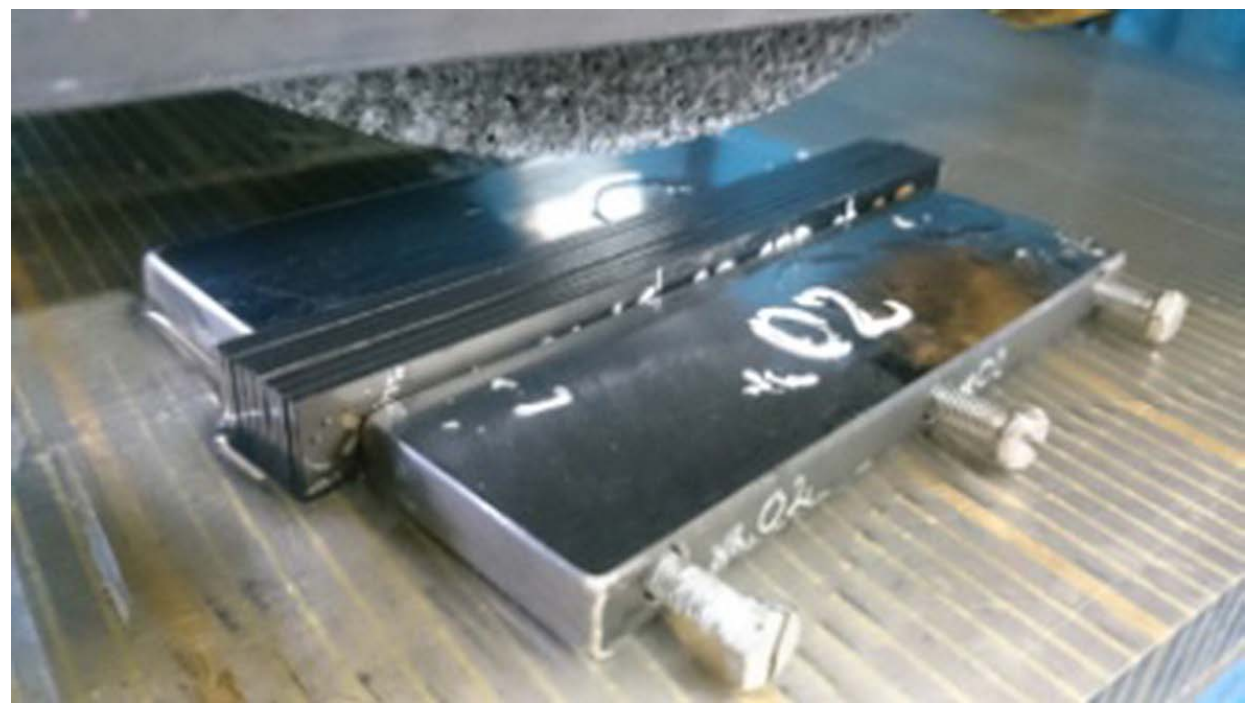

Fig. 7. Samples prepared for grinding [The Author 2016]

\section{QUALITY CONTROL OF THE SAMPLES PRODUCED}

Every research unit should include a quality control department to verify the products for compliance with the applicable documentation. The composite samples delivered by the technology department are standardized and must be prepared in compliance with specified tolerances. Proper preparation is a prerequisite for sample acceptance and for performing strength tests (e.g. tensile, compression, bending, shearing, etc.), which are of great importance when selecting materials for aerial structures [17]. The compliance of the samples with the tolerances given also affects the reliability and reproducibility of the results.

Quality control of composite samples includes the following:

1. Visual inspection of the work surface.

2. Verification of the sample dimensions.

3. Verification of the perpendicularity of the sample surfaces using the simplified method.

4. Verification of the perpendicularity of the sample surfaces under a microscope.

\subsection{Visual inspection of the work surface}

Visual inspection of the work surface is the first stage of quality control, offering quick verification of the elements produced. In this process, the surface of the samples is controlled for scratches and fiber fraying created on the surface and on the edges of the samples during the cutting process. Such defects should be removed in the grinding stage. If scratching or fiber splintering is detected after grinding, the sample is discarded.

Visual inspection of work surface is shown in Figure 8. 

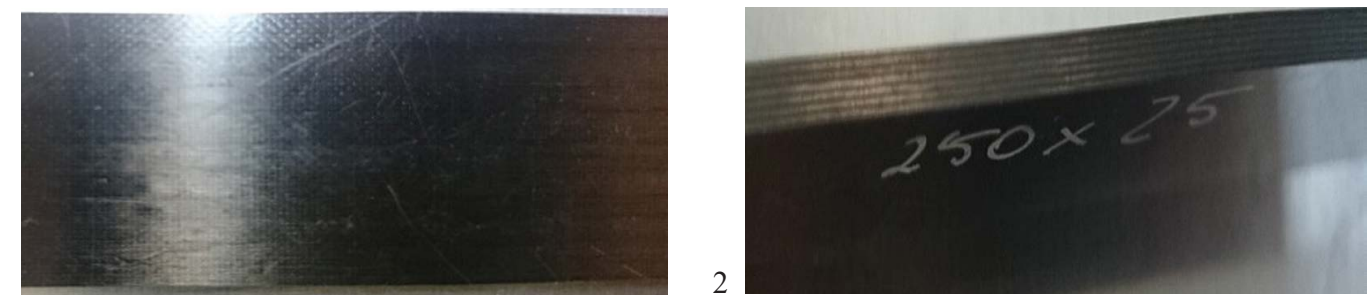

Fig. 8. Visual inspection: 1 - of fiber cohesion, 2 - of grinding uniformity [The Author 2016]

\subsection{Verification of the sample dimensions}

Dimension verification consists of checking the width, length and parallelism of the worked edges of the sample. The dimensions must be within the tolerances specified in the technical documentation or in the standard. The measurement is done in at least three places using an electronic caliper with a valid calibration test. A sample measurement is shown in Figure 9.

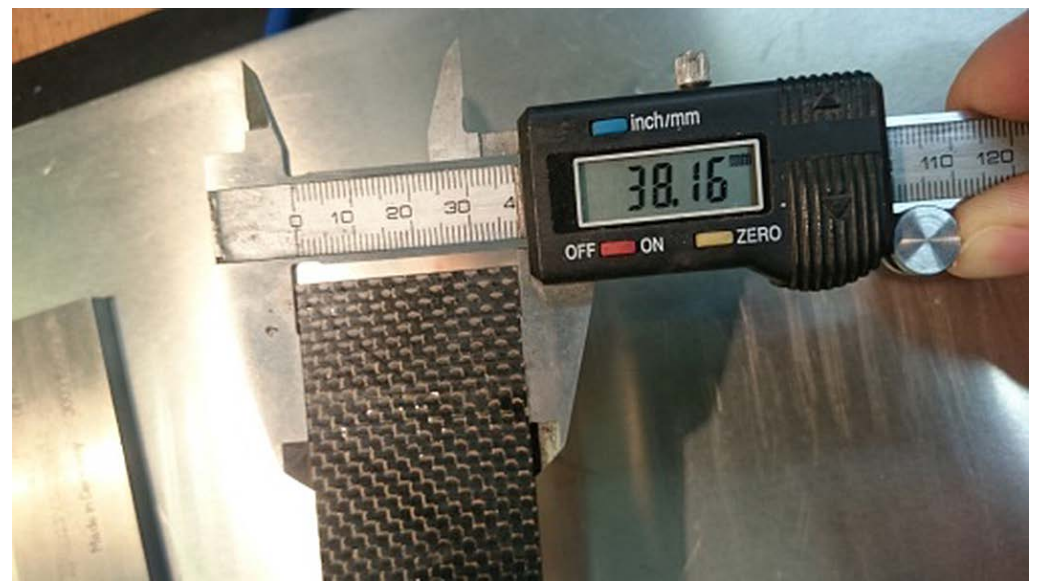

Fig. 9. Checking dimension conformity with documentation [The Author 2016]

\subsection{Verification of the perpendicularity of the sample surfaces using the simplified method}

Compression testing requires that the samples, in addition to the toleranced width, length and parallelism, meet the tolerance of the perpendicularity of the surfaces. As a result, all samples are subjected to $90^{\circ}$ angle verification. Verification of the perpendicularity of the sample by means of the simplified method is based on the use of a precision square with a tolerance grade of 2 (as per DIN 875/2 - for a square with a $150 \mathrm{~mm}$ long leg the squareness tolerance is $35 \mu \mathrm{m}$ [3]), and a $30 \mu \mathrm{m}$ thickness gauge. The edges of the samples must fit the edges of the square with such accuracy that no gap is visible between the edge of the sample and the square and it is impossible to insert a standard $30 \mu \mathrm{m}$ gauge plate between the respective edges. All four angles of each sample are tested with this method. The simplified method of angle verification is shown in Figure 10. 

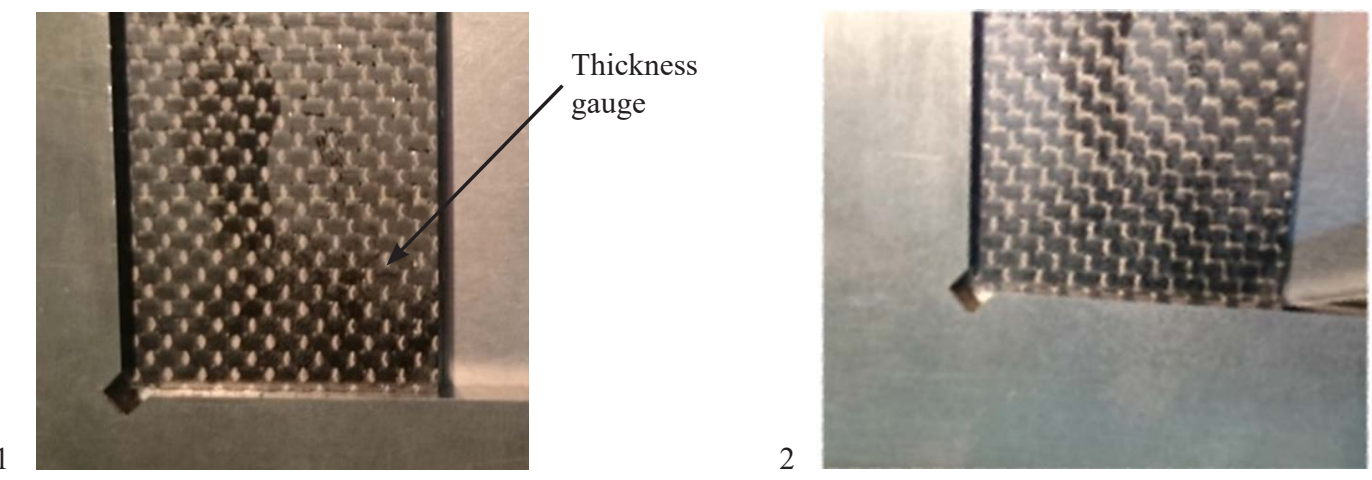

Fig. 10. Measurement of the perpendicularity of the sample with the simplified method: 1 - visual, 2 - with a standard thickness gauge [The Author 2016]

\subsection{Verification of the perpendicularity and the surface of the sample under a microscope}

Examination of the perpendicularity and surface quality of the sample is done using a digital microscope. The measurements are made for a random sample from each series. When measuring perpendicularity, the microscope is calibrated against a gauge block. The microscope is also used to check the quality of the surface grinding and to look for any possible delamination. Delamination is a very dangerous phenomenon because it can affect the load bearing capacity of a panel [5] and it is invisible to the naked eye if located in between the inner layers [4]. Verification of the surface and perpendicularity of the sample under the microscope is shown in Fig. 11.

1

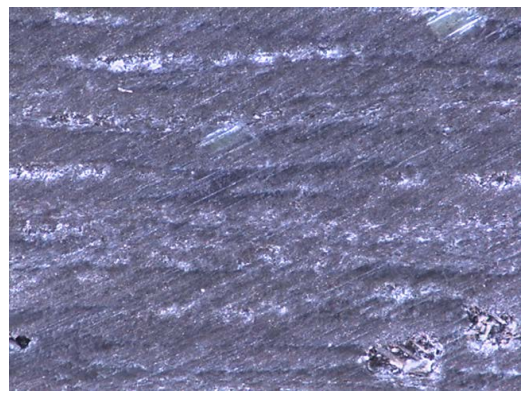

3

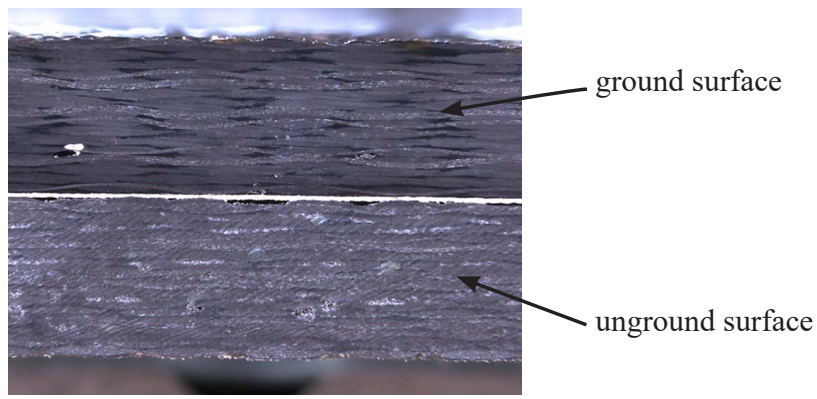

2

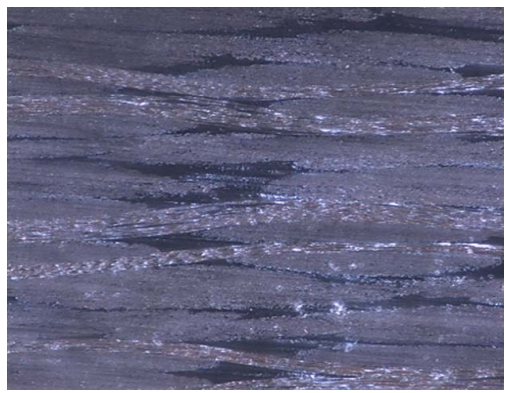

4

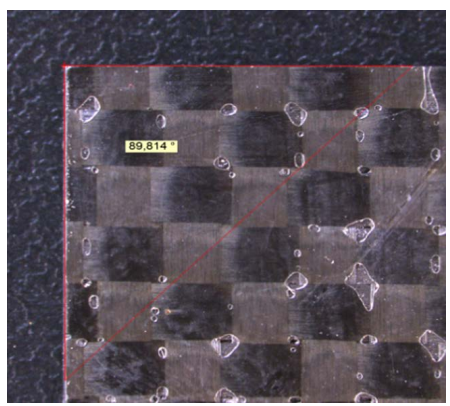

Fig. 11. Verification of the surface and perpendicularity under a microscope: 1 - Surface before grinding, 2 - surface after grinding, 3 - a comparison of sample before and after grinding, 4 - angle measurement on microscope [The Author 2016] 
The composite samples accepted by quality control must be dried prior to the strength test. The drying of samples is done in special furnaces over the period of at least 2 hours at a temperature of about $60^{\circ} \mathrm{C}$. The purpose of this step is reduction of the moisture present in the composite samples, which increased during the wet grinding process. This process should be precise because water absorption leads to swelling of the polymeric material, creating tensile stresses during drying, which in turn increases the material's susceptibility to cracking. The degradation process resulting from the contact of the composite with water and variable temperature (resulting from atmospheric conditions, work or exposure to sunlight) is called aging [6].

\section{CONCLUSIONS}

1. Cutting the samples on a CNC plotter with a cutting speed of more than $130 \mathrm{~m} /$ min results in local overheating of the epoxy resin and fraying of the fibers at the panel edges $\geq 1 \mathrm{~mm}$, which causes the sample to be rejected during quality control.

2. The optimal cutting speed of composite material when cutting on a manual milling machine is $0,1 \div 0,4 \mathrm{~m} / \mathrm{min}$. At these speeds there is no fiber fraying or it is $\leq 0.5 \mathrm{~mm}$ and can be removed through grinding without increasing the grinding allowance.

3. The grinding process makes it possible to satisfy the tolerances of perpendicularity and surface parallelism which are difficult to meet using different methods.

4. The quality control system developed (visual inspection of the work surface, verification of dimensions, verification of surface perpendicularity using the simplified method, verification of surface perpendicularity on the microscope) allows for quick and reliable verification of the samples prepared. The time of the quality control described, including filling in a control report for a 100 sample series, is $100 \mathrm{~min}$.

\section{REFERECES}

[1] Wiśniowski W., Badania i świadczenie usług na światowym rynku badań, Marketing i Rynek, 2014, s. 215-224.

[2] ASTM D6641/D6641M-14 (2014), Standard Test Method for Compressive Properties of Polymer Matrix Composite Materials Using a Combined Loading Compression (CLC) Test Fixture, ASTM International, West Conshohocken, PA, www.astm.org.

[3] http://www.metrica.com.pl/wymagania-dotyczace-katownikow-stalowych-wedlug-din-875-1/.

[4] Jaśkiewicz R. Analiza wpływu parametrów procesu wiercenia na jakość uzyskiwanych otworów i właściwości mechaniczne kompozytów węglowych, Prace Instytutu Lotnictwa, 2016, Nr. 3 (244) s. 65-73.

[5] Phadnis V. a., Makhdum F., Roy a. and Silberschmidt V.V., 2013, "Drilling in carbon/epoxy composites: experimental investigations and finite element implementation", composites Part a: applied Science and Manufacturing 47, pp. 41-51.

[6] Kaczorowska E., Dobór procesu kondycjonowania próbek zgodnie z wymaganiami kwalifikacji kompozytów polimerowych do zastosowań w konstrukcjach lotniczych, Prace Instytutu Lotnictwa, 2016, Nr. 3 (244) s. 85-91. 
[7] Waśniewski B. Duroplasty oraz termoplasty wysokotemperaturowe w prepregach jako osnowy kompozytów węglowych do wytwarzania struktur lotniczych, Prace Instytutu Lotnictwa, 2016, Nr. 2 (243) s. 28-39

[8] Glover, B.M., 2004, "History of development of commercial aircraft and 787 Dreamliner" Aviat. Eng., 592, 16-21.

[9] Pora, J., 2003, “Advanced materials and technologies for A380 structure. Flight airworthiness support technology" Airbus Custom Serv., 32, 3-8.

[10] Soutis, C., 205, “Carbon fiber reinforced plastics in aircraft construction", Materials Science and Engineering: A, 412(1), 171-176.

[11] Wiśniewski A., Kozaczuk K., Building and Testing Composite Objects in Institute of Aviation Institute of Aviation Scientific Publications Division, 2015, s. 242-256.

[12] Kozaczuk K., Zalewska M., Composite testing laboratory performance development based on Lean Sigma approach - case study, Prace Instytutu Lotnictwa, 2016, Nr. 4 (245) s. 60-69.

[13] Wiśniewski A., Sałacińska A., Szymański R., Kunikowska A., Manufacturing of composites samples with graphene, Prace Instytutu Lotnictwa, 2016, Nr. 4 (245) s. 262-270.

[14] Wiśniewski A., Sałacińska A., Wilk J., Impact testing of carbon fiber-epoxy resin composite with graphene, Prace Instytutu Lotnictwa, 2016, Nr. 4 (245) s. 271-279.

[15] Wiśniewski A., Sałacińska A.,Wilk J., Compression after impact testing of carbon-epoxy resin composites samples with graphene, Prace Instytutu Lotnictwa, 2016, Nr. 4 (245) s. 280-286.

[16] Sałacińska AAnaliza wpływu grafenu na właściwości kompozytów węglowo-epoksydowych, Prace Instytutu Lotnictwa, 2016, Nr. 3 (244) s. 137-146.

[17] K. Kozaczuk, Engine nacelles design - Problems and challenges, JOURNAL OF AEROSPACE ENGINEERING, May 2017.

\section{WYTWARZANIE I BADANIE WĘGLOWYCH PRÓBEK KOMPOZYTOWYCH PRZEZNACZONYCH DLA LOTNICTWA}

\section{Streszczenie}

W artykule przedstawiono technologię wytwarzania oraz kontrolę jakości próbek kompozytowych wykonanych z materiałów przeznaczonych między innymi na elementy statków powietrznych. Próbki wykonano z preimpregnatu węglowego w osnowie polimerowej, który powszechnie stosowany jest w przemyśle lotniczym. Opisano wymagania wymiarowe dla próbek wytworzonych z materiałów kompozytowych przeznaczonych do badań wytrzymałościowych oraz główne etapy produkcji, które mają bezpośredni wpływ na jakość próbek kompozytowych. Przedstawiono również proces technologiczny wytwarzania płaskich węglowych paneli kompozytowych przeznaczonych na próbki kompozytowe, cięcie na ploterze $\mathrm{CNC}$ wyprodukowanych paneli, cięcie próbek na frezarce konwencjonalnej oraz obróbkę powierzchni próbek na szlifierce do płaszczyzn. Podano parametry obróbki dla frezowania oraz szlifowania próbek węglowych, które na drodze doświadczeń uznano za optymalne. Opisano sposób przeprowadzania kontroli jakości gotowych próbek kompozytowych oraz przedstawiono rozwiązania usprawniające produkcję próbek o wysokiej jakości.

Słowa kluczowe: prepreimpregnat węglowy, technologia kompozytowa, konsolidacja próżniowa, badania wytrzymałościowe. 